\title{
Three Approaches \\ To Money Stock Determination
}

Movements in employment, output, and prices affect the economic well-being of each member of our society. These movements, in turn, are influenced by the ability and desire of consumers, businesses, and governments to spend, in relation to the productive potential of the economy.

If total demand for goods and services is smaller than the economy's ability to produce, many individuals are unemployed and per capita output of goods and services is below its potential. Such conditions mean that economic welfare is not being maximized. More goods could be produced-with more people sharing the larger output.

On the other hand, total demand in excess of full employment output results in inflation. Rapid increases in prices, particularly during a period of full employment, are generally undesirable. Such increases redistribute purchasing power from fixed income groups to those whose money incomes rise faster than prices. Debtors gain real purchasing power at the expense of creditors. Furthermore, continued inflation discourages saving, encourages speculation, and may reduce future growth in real output.

Government stabilization actions attempt to promote the economic well-being of the nation's citizens by creating an environment conducive to a high level of employment with reasonable price stability. These actions are designed to promote or to restrict advances in total spending to an amount consistent with increases in the nation's productive potential. Growth in the nation's resources and advances in technology provide the basis for expanding output.

Implementation of economic stabilization policy involves both fiscal and monetary actions. Fiscal actions refer to the spending and taxing plans of the Federal Government. Monetary actions refer to the Federal Reserve System's influence on money, credit, and interest rates.

There is a widespread belief today that changes in some magnitude called money infuence spending. As previously noted, changes in spending then affect production, employment, in comes, and prices. The magnitude called money is generally defined in one of two ways. The most common measure consists of the public's holdings of currency and demand deposits at commercial banks. A broader measure expands this definition to include the public's holdings of time deposits at commercial banks.

Knowledge of the basic factors underlying changes in the money stock is of considerable use to economists and other analysts who view money as a strategic economic variable. The following article summarizes and compares three frequently cited approaches for analyzing changes in the money stock. 
ost investigations of factors affecting the money stock take as a starting point total member bank reserves or some other magnitude which constrains the maximum size of the money stock for given reserve requirements. ${ }^{1}$ Federal Reserve actions affecting the volume of total member bank reserves and reserve requirements set a maximum limit on the volume of member bank deposits, thereby having an important bearing on the volume of money outstanding.

There are, however, many other uses of reserves, sometimes referred to as "leakages" or "slippages" in the process of money stock determination. For instance, some reserves are used to meet reserve requirements on time and Government deposits, and some are held as excess reserves. In addition, the volume of currency held by the nonbank public and some other factors affect the size of the reserve base. Most studies of the money stock give consideration to these factors.

Fand has aptly summarized the general problem of money stock analysis: ${ }^{2}$

In money and banking textbooks there is a simple link between bank reserves, deposits, and money. In a world where banks use all their reserves, where there are no free reserves, and where both the banks and the public do not undertake any portfolio changes, there is no need to concern ourselves with the money supply, since it is basically a matter of arithmetic. Once we get away from the simple, mechanical link between reserves, deposits, and money, the supply of money has an independent existence as an economic variable determined by behavior and subject to analysis.

The simple textbook link between bank reserves and money referred to by Fand stems from the Phillips exposition. ${ }^{3}$ According to this analysis, banks are assumed to hold no excess reserves and the public holds

\footnotetext{
1 Samuel Chase and Lyle Gramley in "Time Deposits in Monetary Analysis," Federal Reserve Bulletin, October 1965 dissent from this traditional view. "In this model, banks are not constrained in their ability to supply deposits by the existence of legal reserve requirements or by the level of bank reserves. The required reserve ratio may influence the rates at which an individual bank is willing to supply deposits, but at the rates quoted, the quantity of deposits a bank sells depends on the willingmess of the public to purchase its deposits. Since this is true for each and every bank in the System, the constraint on bank deposits-and henee on bank asset holdingsis derived from the public's destre to hold bank deposits.", $\mathrm{p}$. 1385 .

2 David I. Fand, "Some Implications of Money Supply Anal ysis," American Economic Reviet, May 1967, p. 380.

${ }^{3}$ C. A. Phillips, Bank Credit (New York: Macmillan, 1920).
}

only demand deposits (no currency or time deposits). An injection of reserves into the banking system causes banks to buy earning assets, thereby increasing their demand deposits. The increase in demand deposits (and the corresponding increase in earning assets) is equal to the injection of reserves multiplied by the reciprocal of the reserve requirement ratio on demand deposits. Some money and banking textbooks expand this simplified case to include bank holdings of excess reserves and the public's holdings of currency and time deposits; however, a fully specified theory regarding the behavior of these variables is not generally set forth.

Among the many studies of recent years, three prominent approaches have been developed for analyzing factors affecting the money stock. ${ }^{4}$ These are the Friedman-Schwartz-Cagan approach, the BrunnerMeltzer approach, and the "reserves available" approach. Each of these studies follows the traditional procedure of incorporating some policy controlled variable which, along with reserve requirements, constrains the maximum size of the money stock. They then consider other uses of this controlled variable which keep the actual volume of money below the maximum.

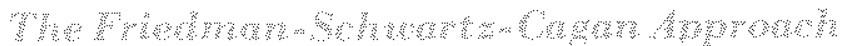

The Friedman-Schwartz-Cagan approach uses an identity to relate money, broadly defined to include time deposits at commercial banks, to three proximate determinants. ${ }^{5}$ In the Friedman-Schwartz study, these determinants are high-powered money $(\mathbf{H})$, the deposit to reserve ratio $(\mathrm{D} / \mathrm{R})$, and the deposit to currency ratio $(\mathrm{D} / \mathrm{C})$. The discussion in the next few para-

\footnotetext{
*The author received many helpful suggestions in writing this article from Professors Milton Friedman, Philip Cagan, Karl Brunner, Allan Meltzer, and David Fand, and from Dr. Anna Schwartz and Miss Elaine Goldstein, However, the interpretation and analysis presented in this article are the sole responsibility of the atthor.

For an outline and discussion of monetary studies during the $1950^{\circ} \mathrm{s}$ and early 1960's, see H. G. Johnson, "Monetary Theory and Policy,"American Economic Review, June 1962, pp. 335-384. The three approaches discussed in this article are only part of the many studies in this area. Recently economists such as DeLeeuw, Teigen, Goldfeld, and Turek have estimated supply functions for demand deposits, based on some earlier works of Meigs and Tobin. For an analysis of these works, see Fand, op. cit., pp. 380-400.

5 Milton Friedman and Anna J. Schwartz, A Monetary History of the United States, 1867-1960, (Princeton: Princeton University Press, 1963), Appendix B. Phillip Cagan uses a very similar approach in Determinants and Effects of Changes in the Stock of Money, 1875-1960 (Princeton: Princeton University Press, 1965). The two books are based on cooperative research conducted by the three authors for the National Bureau of Economic Research.
} 
graphs is based on Friedman-Schwartz. A discussion of Cagan's slightly different approach is presented later. The three proximate determinants reflect the behavior of three sectors of the economy; high-powered money, behavior of the monetary authorities; the deposit-reserve ratio, behavior of the banks; and the deposit to currency ratio, behavior of the public. Underlying each "proximate determinant" are many economic and institutional factors which may be viewed as "ultimate determinants."

High-powered money is an analytical concept frequently cited as a constraint on the maximum size of the money stock. It may be calculated by either of two methods. One method is based on the sources of $\mathrm{H}$; the other is based on its uses (Table I). The Friedman-Schwartz exposition relies on the uses of $\mathrm{H}$-total reserves of member banks plus nonmember bank deposits at Reserve Banks ( $R$ ) and currency held by the nonbank public (C). The other two determinants are the deposit to reserve ratio and the deposits to curm rency ratio. Deposits (D) are defined to include private demand and time deposits at all commercial banks and to exclude Federal Government and interbank deposits.

The deposit to reserve ratio (D/R) depends on legal reserve requirements, expectations of currency flows, and interest rates. It thus embodies the decisions of banks regarding excess reserves. Furthermore, since the ratio is calculated for each period of time by dividing actual $D$ by $R$, changes in the ratio reflect changes in the distribution of deposits among banks with different reserve requirements (both member and nonmember) and changes in the distribution of deposits between demand and time accounts. Changes in the ratio also reflect the distribution between private

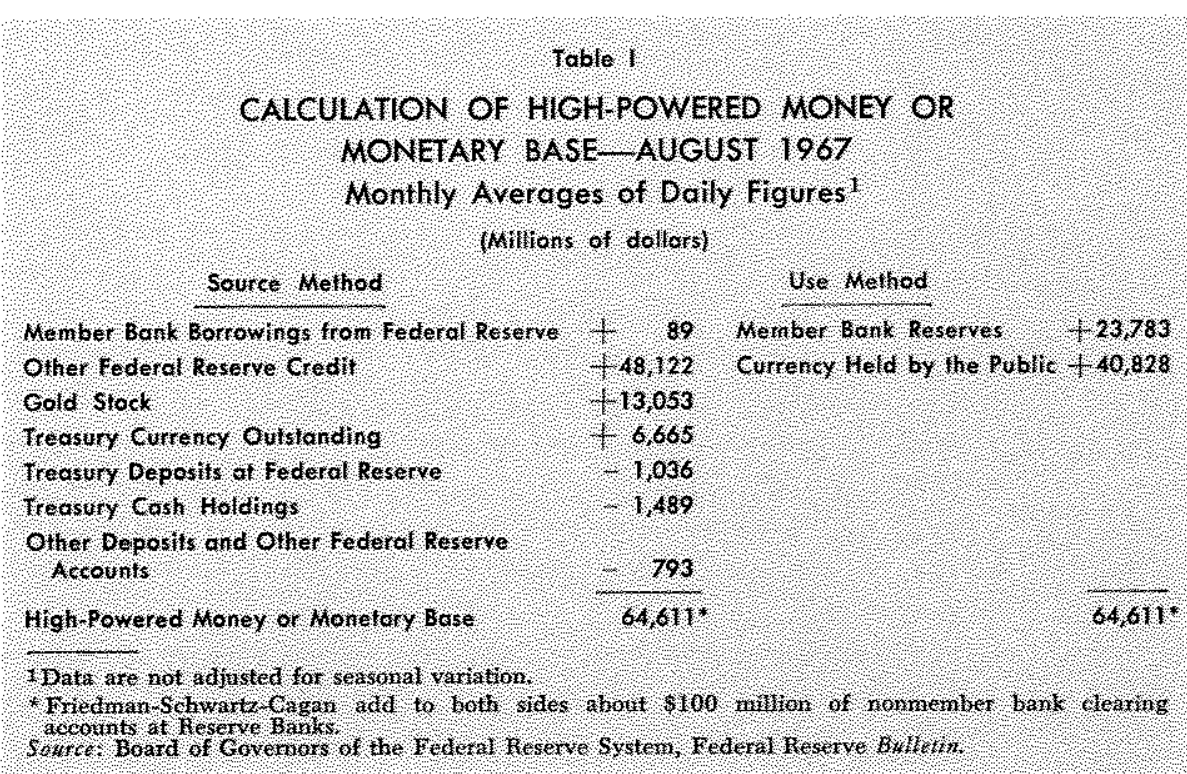

deposits and those excluded from $D$.

The deposit to currency ratio is also calculated from the actual figures for each period. Changes in this ratio depend on interest rates, income, and the public's preference for holding coin and currency.

Friedman-Schwartz present the following money stock identity (where $M$ equals the public's holding of currency, demand deposits, and time deposits) in terms of these three determinants:

$$
M=H \frac{D / R[1+D / C]}{D / R+D / C}
$$

Cagan uses a slightly different form of this identity.

The breakdown of the money supply presented in terms of the three proximate determinants facilitates analysis of the underlying economic factors at work. The part of the identity consisting of the two ratios is called a money multiplier. High-powered money times this multiplier yields the broadly defined money stock. The simultaneous interaction of changes in high-powered money and in the two ratios determines changes in the money supply.

A theoretical process of money supply determination underlies this identity. Monetary authorities provide high-powered money which is viewed as a pool into which banks dip to meet reserve requirements and to obtain desired excess reserves. The public also draws on this pool for currency. Banks and the public thus compete for use of the limited amount of high-powered money provided by monetary authorities. By definition $(\mathrm{H}=\mathrm{R}+\mathrm{C})$ the entire pool is always claimed.

The moving force of this money supply process involves the response of banks to a discrepancy between desired and actual excess reserves. Monetary actions increasing the quantity of $\mathrm{H}$ cause the actual level of excess reserves to be greater than the desired level, given existing financial conditions. Banks acquire earning assets, increasing their deposits and reducing their actual excess reserves to desired levels. This process is partially offset by the higher levels of currency and reserves needed to maintain the desired ratios due to the increase in deposits.

Changes in the money stock also result from changes in either of the ratios, with no 
change in the quantity of high-powered money. This process is further complicated by the fact that the ratios are interrelated. For example, if a change in the deposit to currency ratio leaves the banks with more high-powered money than they desire, the banks will use the extra reserves to acquire assets. This process expands deposits, and thereby leads the public to hold more currency. Even though the proximate determinants of money are under the general control of various economic units and many variables affect them independently, there are also important links between them.

Friedman-Schwartz using this framework concluded from their examination of successive historical episodes in United States monetary experience from 1867 to 1960 that changes in high-powered money were by far the dominant determinant of long-term and major cyclical movements in the broadly defined money stock. Changes in the two ratios exerted an important influence on movements in money in financial panics, and changes in the deposit to currency ratio made a significant contribution to movements in money during mild cycles.

Cagan used the same money supply framework as Friedman-Schwartz; however, he arranged the three proximate determinants in a different form in his identity. In Cagan's identity currency is expressed as a ratio to money $(\mathrm{C} / \mathrm{M})$ and reserves as a ratio to deposits $(\mathrm{R} / \mathrm{D})$.

$$
M=\frac{H}{C / M+R / D-C / M ~ R / D}
$$

Using this framework, Cagan presented a statistical and descriptive analysis of the economic factors accounting for the relative contribution of each proximate determinant to secular and cyclical changes in the money stock from 1875 to 1960 . Cagan examined the underlying factors influencing movements in money in greater detail than Friedman-Schwartz. His conclusions generally were applied to two periods1875 to 1914 , when the Federal Reserve System was started, and 1914 to 1960 . This discussion presents primarily his conclusions for the latter period.

The dominant factor influencing long-term growth in money has been growth in high-powered money. This, in turn, has been influenced since 1914 equally by movements in gold stock and Federal Reserve operations. The two ratios have contributed little to secular changes in money.

With regard to cyclical movements in money, he concluded that cyclical movements in the currency to money ratio were most important, the reserve to deposit ratio had only a minor impact, and changes in highpowered money exerted an irregular effect which did not correspond very closely to cyclical movements in money. Cyclical movements in $\mathrm{C} / \mathrm{M}$ were primarily the result of movements in economic activity; he found that currency responded primarily to changes in the rate of consumer spending for goods and services. Short-run changes in $R / D$, which reflect to a considerable degree changes in bank holdings of excess reserves, were found to reflect changes in economic activity. Interest rate changes had little impact on movements in this ratio. After 1914 Treasury and Federal Reserve operations were prime contributors to short-run movements in high-powered money. It was pointed out that System operations seldom were carried out for the purpose of influencing movements in money.

Since it was found the cyclical changes in money were influenced by changes in economic activity via the $\mathrm{C} / \mathrm{M}$ ratio, the question arose regarding the direction of causation. Cagan concluded that in severe business contractions declines in the rate of monetary growth were the main reason for such slow-downs. For mild cycles, the conclusion was reached that there existed a mutual interaction between monetary growth and movements in business activity.

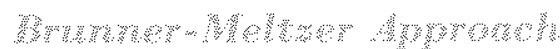

Brunner-Meltzer develop a money supply function and estimate its parameters. This function is a behavioral relation based on their theoretical model of the money supply process. Factors underlying the monetary behavior of banks and the public are specified and entered directly in the money supply function. This discussion of the Brunner-Meltzer approach summarizes only the main thread of a very complex analysis. ${ }^{6}$ Moreover, it considers only one of their approaches which they call the linear hypothesis.

Brunner-Meltzer adopt high-powered money as the variable limiting the maximum size of the money stock, calling it the monetary base (B). They use the source method of computing the base (Table I). This base is directly controlled by the Federal Reserve through open market operations and the discount rate. This infers that System actions can offset changes in the base resulting from changes in the other sources. Other factors included in the function are currency

6 Karl Brumer and Allan Meltzer, "Some Further Investigations of Demand and Supply Functions for Money,"The Jotunal of Finance, May 1964, pp. 247-248. Also see their paper, "An Altemative Appruach to the Monetary Mechanism," G.P.O., 1964 . 
held by the public (C), time deposits at commercial banks ( $T$ ), and bank excess reserves (ER).

The public's holdings of currency and time deposits are postulated to depend on two sets of forces-money wealth and other economic factors. The portion of a change in $\mathrm{C}$ or $\mathrm{T}$ directly related to a change in money wealth (defined as the sum of $\mathrm{C}, \mathrm{T}$, and private demand deposits) is referred to as the "spillover effect," i.e., an increase in money wealth increases the amounts of $\mathrm{C}$ and $\mathrm{T}$ held. The rest of the change in $\mathrm{C}$ or $\mathrm{T}$ depends on various interest rates, costs of checking and time deposit accounts, and nonmoney wealth. $\mathrm{C}_{0}$ and $\mathrm{T}_{0}$ are used to denote the part of $\mathrm{C}$ and $\mathrm{T}$ influenced by these variables.

Changes in bank holdings of excess reserves are similarly partitioned into two parts. The first part is a direct spillover effect in which a change in ER is in duced by a change in bank total private deposits. The other part of a change in $\mathrm{ER}$ depends on reserve requirements, costs of holding ER (interest rates), and costs of reserve deficiencies. This part is denoted by $\mathbf{E R}_{\mathrm{f}}$.

From these considerations, functions for money, both narrowly and broadly defined, are developed. Since most of the Brunner-Meltzer work is devoted to the narrow definition of money, that definition is used below:

$M=m_{0}+m_{1}(B+L)-m_{2} C_{0}-m_{3} T_{0}-m_{4} E R_{0}$.

In this function, $\mathrm{M}$ is money narrowly defined and $m_{1}$ is a money multiplier. The size of $m_{1}$ depends on average reserve requirements; the currency, time deposit, and excess reserve spillover effects mentioned above; and the pattern of interbank payments. The expression $\mathrm{B}+\mathrm{L}$ is called the extended monetary base. This includes the monetary base (B) and reserves "liberated" (released or absorbed) by reserve requirement changes and shifts in deposits between classes of member banks, between nonmember and member banks, and between time and demand deposits. These liberated reserves are called $L$. The first term in the money supply function $\left(m_{0}\right)$ is a constant and the next term, $\mathrm{m}_{1}(\mathrm{~B}+\mathrm{L})$, may be viewed as the average response of money to a change in the extended base.

The remaining three terms represent the influence of economic factors other than the spillover effects included in the money multiplier. In the order of their appearance, these are a part of currency held by the nonbank public $\left(\mathrm{m}_{2} \mathrm{C}_{0}\right)$ a part of time deposits at commercial banks $\left(\mathrm{m}_{3} \mathrm{C}_{0}\right)$, and a part of member bank demand for excess reserves $\left(m_{4} E R_{0}\right)$. The m's in these three expressions are also multipliers, but they have values different than $m_{1}$. The money supply function of their linear hypothesis does not involve Government demand deposits, but these deposits are considered in some of their other works.

The money supply process underlying this formulation is similar to the one developed by FriedmanSchwartz. Surplus excess reserves are again the driv. ing force leading to changes in money. For example, a change in the monetary base leads to surplus reserves, i.e., a discrepancy between actual and desired excess reserves. Banks eliminate these surplus reserves by adjusting their holdings of earning assets, which results in corresponding changes in their deposits. In the process money wealth and bank deposits expand and there are spillover effects into $\mathrm{C}, \mathrm{T}$, and ER. These effects are reflected in the size of $m_{1}$. The money stock changes by an amount equal to $m_{3}$ times the change in the extended base. Surplus reserves can also arise from changes in $\mathrm{C}_{n}, \mathrm{~T}_{n}$, or $\mathrm{ER}_{n}$, with no change in $\mathrm{B}+\mathrm{L}$. The resultant change in the money stock will equal the change in $\mathrm{C}_{0}, \mathrm{~T}_{0}$, or $\mathrm{ER}_{0}$ times its multiplier $\left(\mathrm{m}_{2}, \mathrm{~m}_{3 ;}\right.$, or $\left.\mathrm{m}_{4},\right)$. These multipliers are negative.

The Brunner-Meltzer approach incorporates the same major determinants of the money stock as does the Friedman-Schwartz approach, but in a different manner. The Brunner-Meltzer money multipliers(m's) are empirical relationships estimated by statistical procedures, while the Friedman-Schwartz multiplier is definitional. Brunner and Meltzer have investigated in great detail the economic forces underlying the demand of the public for currency and time deposits and bank demand for excess reserves.

Brunner-Meltzer found that movements in the extended monetary base and the public's currency behavior have primarily determined movements in the money stock. The empirical money multiplier $\left(\mathrm{m}_{1}\right)$ for narrowly defined money is around 2.5, implying a change in money which equals two and a half times a change in the extended monetary base. Another finding was that System open market transactions were a major determinant of variations in the monetary base and, hence, in the money stock. Except for the 1930's, they also found that the money stock was little affected by interest rates.

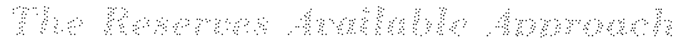

The "reserves available" approach to money stock analysis has been used extensively by this Bank. ${ }^{7}$ Since

\footnotetext{
${ }^{7}$ Data and charts of reserves available for private demand deposits appear in this Bank's, "Monetary Trends," a monthly release, and "U.S. Financial Data," a weekly release. For a discussion of this approach see: Leonall C. Andersen, "Federal Reserve Open Market Transactions and the Money Supply,"
} 
private demand deposits at member banks are the major portion of the money stock, this approach focuses primarily on the factors intervening between open market transactions and changes in the member bank demand deposit component of money (Table II).

Athough an identity is used, the reserves available approach differs from the previous two in that it works through member bank reserves. First, changes in member bank total effective reserves are examined. ${ }^{8}$

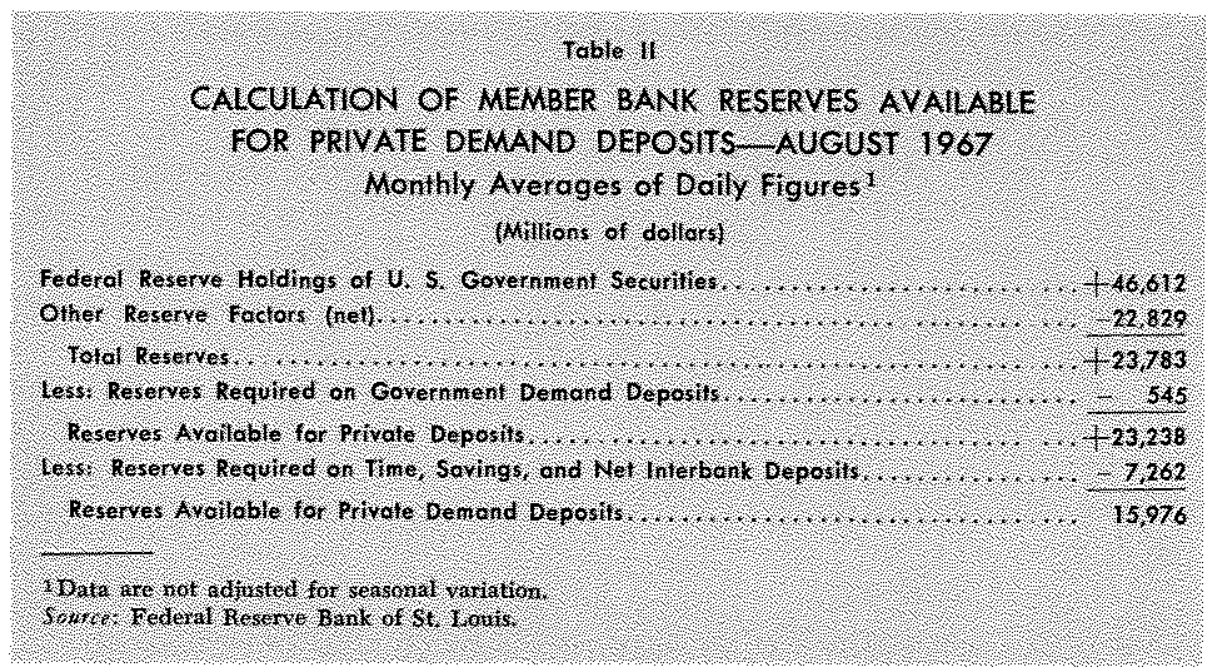
These changes stem from System open market transactions and from all the other factors supplying and absorbing reserves. Major items supplying reserves are member bank borrowings from Reserve Banks, Federal Reserve float, Treasury currency outstanding, and the gold stock. Some factors absorbing reserves are Treasury balances at Reserve Banks, Treasury cash holdings, and currency held by the public.

In the next step, member bank reserves available for private deposits are calculated by subtracting from total reserves those reserves required for U. S. Government deposits. This measure is sometimes used to explain changes in money stock plus time deposits.

Then reserves used to support time and net interbank deposits are subtracted to obtain reserves available for private demand deposits. Finally, member banks are viewed as allocating these available reserves to excess reserves and reserves required on private demand deposits. Multiplication of required reserves by the reciprocal of the average reserve requirement (required reserve ratios specified by the System weighted by the distribution of private demand deposits among classes of member banks) yields the volume of private demand deposits at member banks. The total money stock figure is obtained when nonmember bank private demand deposits and currency held by the public are added to the private demand deposits of member banks.

(Continted from Col. 2, Page 10)

Money and Finance: Readings in Theory, Poticu, and Institutions, Deane Carson, ed., Wiley, N. Y., 1966, pp. 23-31. The original article appeared in this Review, April 1965.

8 Total reserves adjusted for reserve requirement changes. This adjustment is the following: (a) required reserves for past periods are calculated on the basis of most recent reserve requirements; (b) these standardized required reserves are then seasonally adjusted; (c) unadjusted excess reserves are added to the data obtained under (b).

Using the sequence of computations just outlined, all of the "slippages" between open-market transactions and the money stock are accounted for. Prime emphasis is given to the steps leading to changes in the member bank demand deposits component of money, in order to identify the effect of Federal Reserve actions on monetary expansion.

The money supply mechanism underlying the reserves available approach is quite similar to that embodied in the other two approaches. An increase in System holdings of U. S. Government securities, assuming no change in other proximate determinants, increases member bank actual excess reserves relative to their desired level. These banks then expand earning assets and private demand deposits until desired and actual excess reserves are equal. A change in the other proximate determinants, assuming no change in total reserves, directly changes the amount of member bank private demand deposits. Since this approach is designed for purposes of analyzing short-run movements in money (a week to one or two months), it assumes that System actions have little or no effect on any of the other proximate determinants.

The complete procedure presented above using the reserves available approach to money stock determination is useful in examining proximate causes of observed changes in the money stock. The assumption that each slippage is independent of System actions implies that the impact on money from changes in the slippages can be completely offset by such actions. The Federal Reserve would thus be able to achieve a target level of money stock or private demand deposits. However, control would be lost over such other monetary variables as interest rates and bank credit.

A study incorporating many of the concepts of the reserves available approach investigated the relative contributions of many proximate determinants to 
month-to-month changes in money, narrowly defined. ${ }^{9}$ The conclusions reached were that month-to-month changes in money (not seasonally adjusted) were dominated by changes in Federal Reserve holdings of U. S. Government securities; changes in a variable consisting of the sum of the gold stock, Treasury accounts, and minor Federal Reserve accounts; and changes in currency held by the nonbank public. At times other factors such as member bank borrowing from Reserve Banks, member bank excess reserves, Federal Reserve float, and Government demand deposits contributed significantly to changes in money.

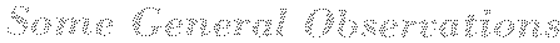

The three approaches summarized in this article for analyzing factors determining the money stock are all of the same general nature. Each is based on the same set of accounting identities, and each can be adjusted to define money in the narrow sense or in the broader sense (i.e., including time deposits at commercial banks). Furthermore, each takes into consideration the same general set of factors in the process of money stock determination-the behavior of monetary authorities, commercial banks, and the public.

These approaches differ in structural form and in the precise definition of the constraining variable and the controlled monetary variable. The FriedmanSchwartz-Cagan approach and the reserves available approach remain in the identity form, while the Brunner-Meltzer approach moves on to a more complex money supply function. However, the identities are used to summarize the proximate determinants of money, and the influence of each on movements in money are examined. Cagan goes a step further and investigates the factors underlying each proximate determinant.

The high-powered money approach and the monetary base approach constrain the size of the money stock by the pool of funds available to satisfy two competing monetary demands-bank demands for reserves and the public's demand for currency. By contrast, the reserves available approach focuses only on that part of the pool remaining after the public's currency demand is filled.

Those who use high-powered money or the monetary base typically examine the determinants of the whole money stock; those who use reserves available attempt to explain only one part, i.e., the member bank demand deposit component. In a sense, the reserves available

9 Leonall C. Andersen, "A Study of Factors Affecting the Money Stock: Phase I," Staff Economic Studies, Board of Governors of the Federal Reserve System, October 1965. approach is a special case of the more general highpowered money or monetary base approaches.

The approaches also differ in the specific uses for which they were designed. Friedman-Schwartz describe movements in money and examine the underlying causes during various episodes of monetary history from 1867 to 1960 . Cagan focuses his attention on explaining statistically the factors underlying movements in money over roughly the same time span. These three economists also relate changes in money to changes in economic activity. Brunner and Meltzer develop their money supply function with a view to achieving specific knowledge of the money supply process. Their money supply function, since it provides measurements of the response of banks and the public to economic forces, is proposed as an aid to monetary management. The reserves available approach is designed to facilitate short-run monetary management, insofar as it involves the money stock.

Several implications for short-run monetary management may be drawn from the discussions of the three approaches presented in this article. A major implication is that System actions through their impact on high-powered money (or monetary base) can have a significant bearing on movements in the money stock. The finding of the reserves available approach that System open market operations are a major source of month-to-month movements in money gives added evidence supporting this implication. Cagan's finding that movements in high-powered money frequently were out of phase with cyclical movements in money does not negate this proposition, because System actions, which explain most of the change in high-powered money, have usually been based on considerations other than influencing changes in money.

Another implication is that the behavior of the public's holding of currency should be given greater consideration in monetary management. The findings using all three approaches were that currency movements played an important role in explaining short-run changes in money.

Cagan's finding that cyclical movements in currency held by the public are primarily determined by changes in economic activity is of great importance. Currency holdings were found to vary in the same direction as cyclical movements in economic activity. According to all three approaches, a rise in currency taken alone decreases the money stock. Hence, a change in economic activity induces an opposite change in the money stock; a rise in spending increases currency held by the public which in turn lowers the money stock. The often observed pro-cyclical movements in money thus result from changes in other proximate determinants 
which more than offset the opposite influence of currency.

Several factors which usually have been thought to exert a major influence on movements in money were found to be of little significance in the studies cited. All three studies conclude that behavior of banks and of the public (except for its behavior regarding currency) is of minor importance in explaining short-run movements in money. Furthermore, economic forces such as interest rates were found by Brunner-Meltzer and Cagan to have little influence on movements in money. The distribution of deposits between demand and time accounts, between classes of member banks, and between nonmember and member banks were found in several of the studies to have only a minor affect on the behavior of money. Such non-market determined forces as expectations of banks and the public may play an important role in accounting for changes in money during times of severe depressions or the older so-called "panics", but not in normal times.

Finally, it appears reasonable to conclude, on the basis of these findings, that the Federal Reserve System could control with a high degree of precision movements in the money stock. No examination has been made in this article of the extent to which use of each approach would facilitate short-run management of the money stock. This important topic is left for a future study.

LEONALL, C. ANDERSEN

This article is available as reprint series No. 24; see page 2 in this issue. 